\title{
Советская военная миссия \\ 1941 года в оценке британской и американской прессы
}

\author{
Вера Шелястина
}

С началом Великой Отечественной войны одной из важнейших внешнеполитических задач СССР становится задача налаживания союзнических отношений. Для решения этого вопроса Государственный комитет обороны принимает решение о командировании Советской военной миссии в Великобританию и Соединенные Штаты Америки. В статье рассматривается ход переговоров на этапе формирования антигитлеровской коалиции (июль-сентябрь 1941 г.) и освещение визита советских военных специалистов в британской и американской прессы.

Ключевые слова: Советская военная миссия 1941 г., антигитлеровская коалиция, военные поставки, ленд-лиз, пресса о визите миссии.

@ Шелястина Вера Олеговна старший преподаватель кафедры зарубежной журналистики и литературы факультета журналистики МГУ имени М.В. Ломоносова (Москва, Россия), veraol@yandex.ru

\section{Введение}

Нападение фашистской Германии на Советский Союз 22 июня 1941 г. в корне изменило международную обстановку. С началом Великой Отечественной войны меняются и внешнеполитические задачи, которые необходимо было решить руководству СССР. Одной из главных можно назвать необходимость скорейшего формирования единого фронта противодействия гитлеровской Германии. Эта точка зрения была озвучена И.В. Сталиным в его обращении к советскому народу 3 июля 1941 г. В речи Верховного главнокомандующего было упомянуто выступление по радио премьер-министра Великобритании У. Черчилля 22 июня. Также отмечена позиция правительства Содиненных Штатов Америки, высказанная Президентом Ф. Рузвельтом на пресс-конференции в Белом доме 24 июня. Руководители этих государств уже в первые дни войны высказались за поддержку Советского Союза. В своем выступлении Сталин прямо назвал народы Европы и Америки «верными союзниками», отметив, что "историческое» выступление У. Черчилля и декларация правительства США о готовности оказать помощь Советскому Союзу являются «понятными и показательными»1. 
В начале июля 1941 г. положение на фронтах было крайне тяжелым, не хватало техники, вооружения. Фронту требовалась реальная помощь, необходимо было как можно скорее добиться практической реализации обещаний премьер-министра Великобритании У. Черчилля, прозвучавших в его выступлении 22 июня в эфире радиостанции ВВС.

С этой целью было принято решение командировать Советскую военную миссию в Великобританию. Постановление о составе миссии было утверждено на заседании Государственного комитета обороны 5 июля 1941 г. Главой миссии был назначен заместитель начальника Генерального штаба, начальник Разведывательного управления Генерального штаба Рабоче-Крестьянской Красной Армии генерал-лейтенант Филипп Иванович Голиков.

До настоящего времени военные историки не дают полного ответа на вопрос, почему Сталин принял такое кадровое решение: Голиков с дипломатической работой знаком не был, опыта переговоров с представителями иностранных держав не имел, английским языком практически не владел². Да и сам Филипп Иванович позже в своих мемуарах напишет: «...полученное здание было несвойственно всему моему жизненному опыту»³. Возможно, что при назначении учитывался опыт Голикова как строевого командира, хорошо знавшего армию изнутри, а также опыт работы (пусть и небольшой) в качестве заместителя начальника Генерального штаба и руководителя военной разведки.

В состав миссии также вошли контр-адмирал Н.М. Харламов, полковник Г.П. Пугачев, полковник В.М. Драгун, майор А.Ф. Сизов и военный инженер 3-го ранга П.И. Баранов. Военный атташе полковник И.А. Скляров и майор Б.Ф. Швецов присоединились к ним в Лондоне.

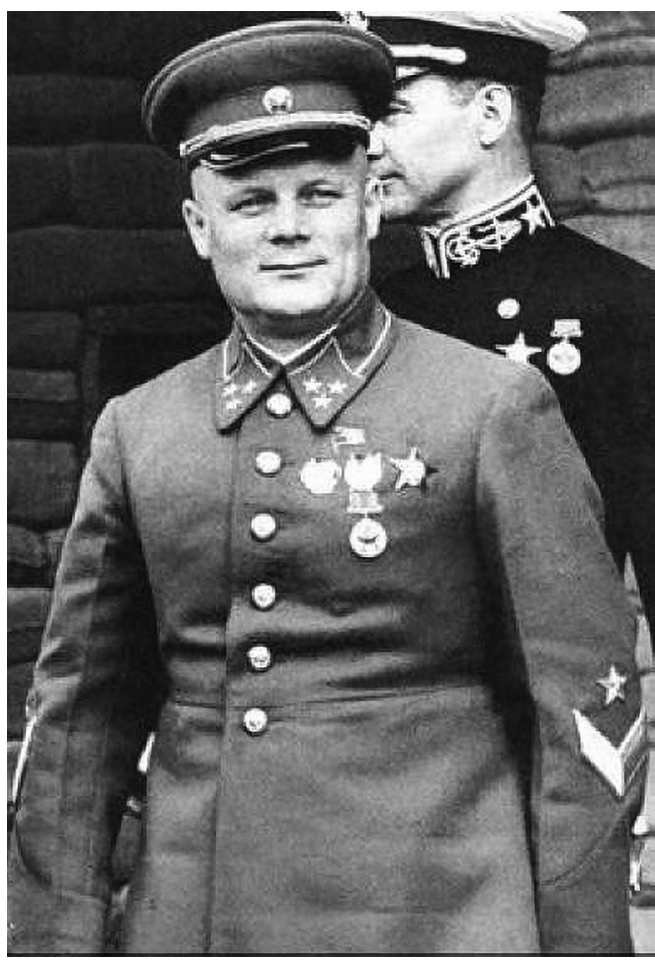

Глава Советской военной миссии генерал-лейтенант Ф.И. Голиков

Накануне вылета в Лондон Ф.И. Голиков был принят И.В. Сталиным, и глава миссии получил конкретные поручения по проведению переговоров. Исходя из потребностей фронта, миссия должна была поставить следующие вопросы:

- договориться о поставках вооружения;

- обратиться к правительству Великобритании с предложением начать военные действия против Германии в Европе, то есть провести переговоры об открытии второго фронта.

В советской исторической литературе этот этап переговоров практически не освещался. В 1969 г. в журнале «Новая и новейшая история» был опубликован отрывок из книги воспоминаний Ф.И. Голикова «Советская военная миссия в Англии и США». Сама книга была опубликована уже после смерти маршала 


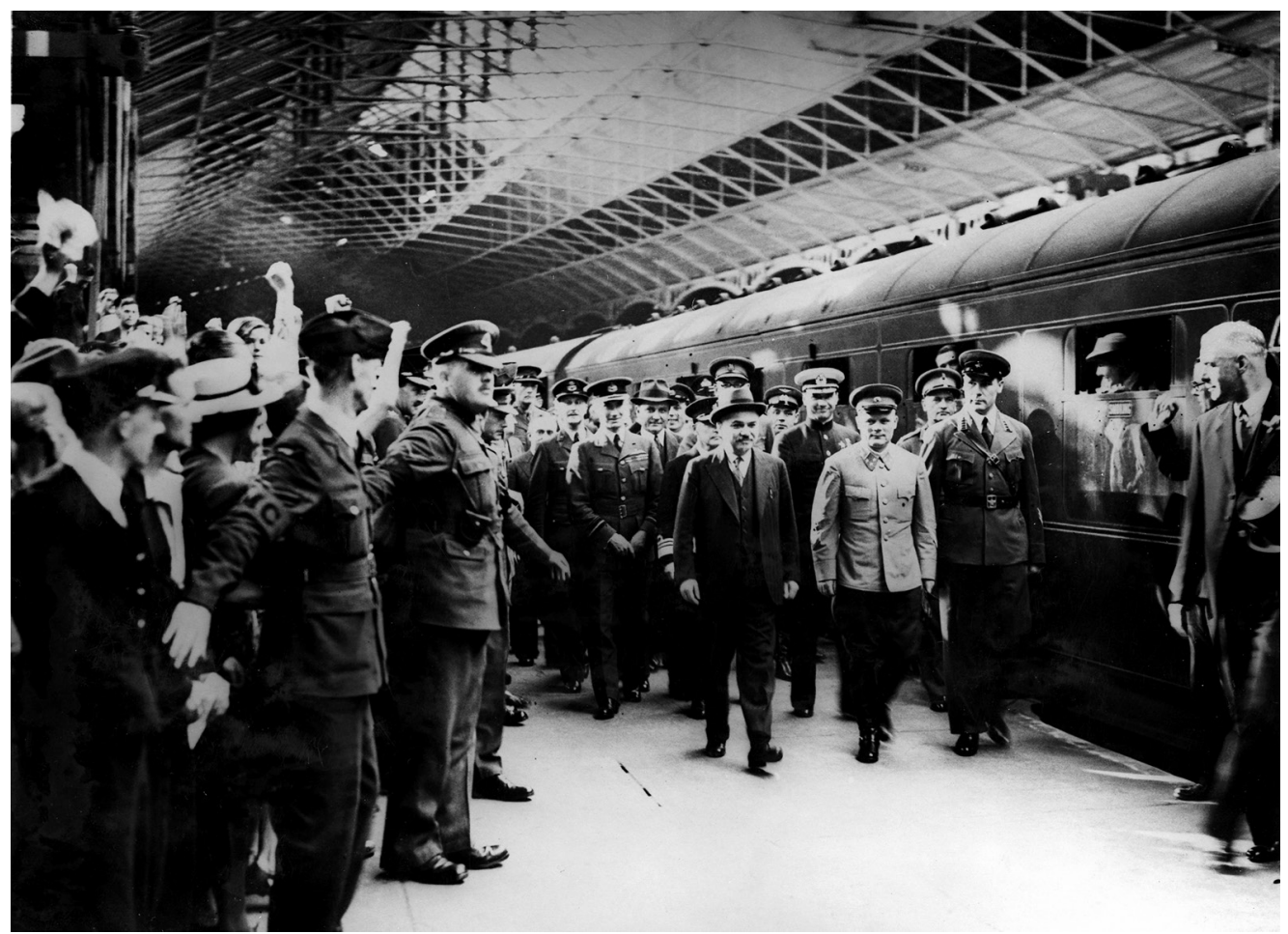

На вокзале в Лондоне

8 июля 1941 г.

(звание маршала было присвоено Ф.И. Голикову в 1961 г. - В.Ш.), сначала в издательстве «Прогресс» на английском и испанском языках, на русском - только в 2004 г. Работа миссии упоминается в книге В.М. Бережкова «Рождение коалиции»4, О.А. Ржешевского «История второго фронта: война и дипломатия»5. Только в последние два десятилетия появились исследования, в которых содержится новая информация и новые оценки роли Советской военной миссии во главе с Ф.И. Голиковым.

В статье рассматривается оценка британской и американской прессой начального периода работы миссии, хронологические рамки исследуемого периода ограничены июлем-августом 1941 г. - первыми днями пребывания советских военспецов в Великобритании и США.

\section{The Guardian: «Интересы Британии и СССР в войне против Германии имеют много общего»}

Советская военная миссия вылетела из Москвы вечером 6 июля в Архангельск, далее - на летающих лодках «Каталина» английских ВВС уже в Великобританию. Полет длился почти 20 часов. Прибыли в Шотландию в Инвергордон. Еще две пересадки уже на поездах, и 8 июля к 19.30 миссия прибыла на лондонский вокзал.

Ф.И. Голиков отмечает, что встреча советской делегации была «...теплой и сердечной. Это не было каким-то организованным митингом <...> Сотни людей с пением "Интернационала" и красными транспарантами устремились на перрон. Из толпы слышались возгласы Welcome»6. (Здесь речь идет о неофициальных лицах, 


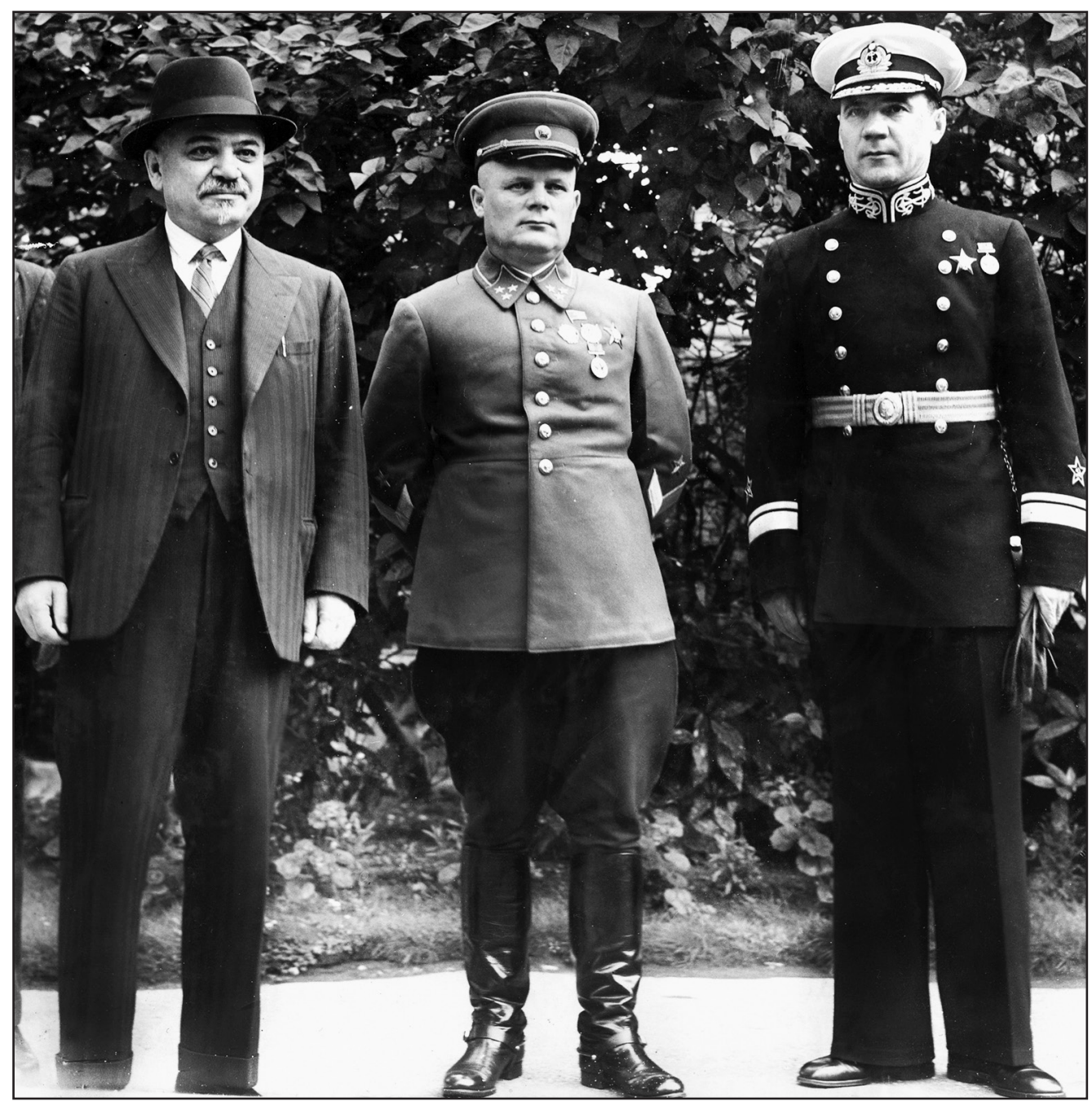

Ф.И. Голиков с послом СССР в Великобритании И.М. Майским и Н.М. Харламовым (справа) Лондон, июль 1941 г.

жителях Лондона, которые стихийно собрались на вокзале).

Из официальных лиц Советскую военную миссию встречал заместитель начальника Имперского Генерального штаба генерал Г. Паунелл и группа британских военных. Ю.В. Рубцов отмечает, что члены миссии «...были встречены с соблюдением всех норм протокола, но без особой сердечности». Английские военные продемонстрировали «безупречную корректность»7.
На 9 июля были назначены первые встречи, и день получился очень насыщенным. Утром миссия направилась в Министерство иностранных дел, где советский посол И.М. Майский представил членов миссии министру иностранных дел А. Идену. Далее состоялись переговоры с руководителем военного ведомства Г. Моргенсоном, с начальниками главных штабов вооруженных сил (генерального штаба, военно-воздушных сил, военно-морских 


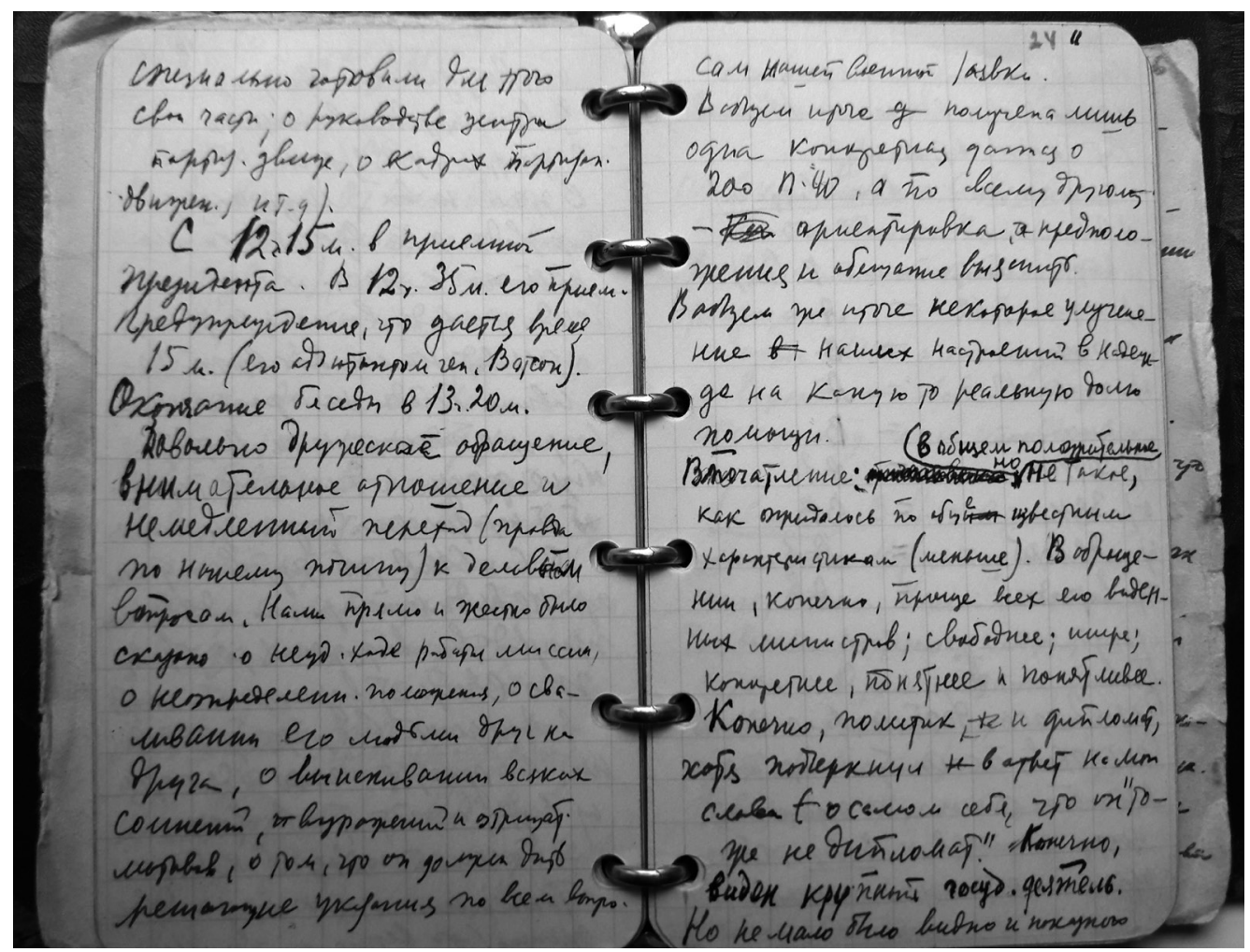

Записная книжка Ф.И. Голикова

сил). В последующие дни также состоялись встречи с Первым лордом Адмиралтейства А. Александером, министром ВВСА. Синклером. И здесь членов миссии ждало разочарование. Как писал Ф.И. Голиков, «...сказать, что поведение наших партнеров на протяжении всей беседы было подчеркнуто формальным, значит сказать очень мало»8. Г. Моргенсон даже не предложил сесть. "В стоячку» - так записал Ф.И. Голиков в своей записной книжке 9.

Визит Советской военной миссии широко освещался британской прессой. The Guardian подчеркивала, что миссия «положила начало сотрудничеству России и Великобритании в противодействии войне» 10 .

The Times отмечала, что подобное сотрудничество между странами можно охарактеризовать как «хорошую работу». Га-

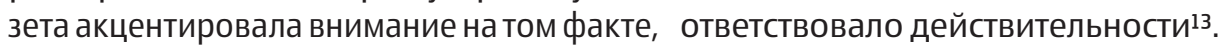

что именно Советскому Союзу как никому другому хорошо известно положение дел на фронтах ${ }^{11}$. Также The Times положительно отзывалась о работе миссии, назвав ее работу «уверенной», а членов миссии «увлеченными людьми, которые смогли убедить Британию в своей максимальной заинтересованности в сотрудничестве, а также в том, что Советская армия способна противостоять Германии»12.

Такой положительный «настрой» британской прессы в первые дни работы миссии отмечает в своих воспоминаниях и Ф.И. Голиков. Но тем не менее он подчеркивает, что порой газеты выдавали желаемое за действительное и торопились сообщать читателю недостоверные факты. Например, о начале поставок военных материалов в Советский Союз, что на тот момент не со85 
Большой интерес британские издания проявили не только к работе миссии, но и к офицерам в ее составе. В первую очередь к главе миссии генерал-лейтенанту Голикову и его заместителям контр-адмиралу Харламову и полковнику Пугачеву. The Guardian назвала их «главными военными экспертами» 14 .

The Times проявила интерес к полковнику Пугачеву: внимание газеты привлекла его фамилия, и издание даже опубликовало историческую справку о восстании Емельяна Пугачева. Газета не раз обращалась к историческим параллелям. The Times убеждена, что Германии придется повторить слова Наполеона: «Эти русские храбрецы. Они держатся и сражаются, невзирая на то, что могут быть убиты»15. Ф.И. Голикова The Times охарактеризовала как «одного из наиболее выдающихся советских офицеров»16, что категорически не принял сам Голиков, назвав персональные характеристики членов миссии «домыслами»17.

Положительная оценка работы миссии и слова поддержки в адрес Советского Союза британскими газетами значительно отличалась от той атмосферы, которая порой складывалась на переговорах. Британское военное руководство проявляло осторожность, не веря в успех Советского Союза в борьбе против Гитлера. Это отмечала The Manchester Guardian: «...русские ведут смертельную борьбу с врагом <...> им нужна незамедлительная помощь, а не красивые обещания. Всякая задержка может оказаться для них критической, и они считают, что в Великобритании имеет место опасная тенденция неправильной оценки создавшегося положения»18.

Тем не менее, несмотря на трудности, первые переговоры можно назвать успешными: миссия передала представителям британской стороны списки заказов на вооружение и стратегические материалы. Большим успехом можно назвать договоренности о совместных операциях в Арктике. «Обещания Черчилля об оказании помощи начали обретать конкретные формы», - пишет В.И. Лота19. Обсуждение же вопроса об открытии второго фронта не дало положительных результатов.

\section{Миссия в США. Сдержанность в переговорах и в оценке американской печатью}

Двенадцатого июля Ф.И. Голиков был вызван для доклада в Москву. Обратная дорога заняла более трех дней. На встрече со Сталиным, которая состоялась 17 июля, Филипп Иванович получает новый приказ - срочно вылететь в Соединенные Штаты Америки. Задача та же - налаживание союзнических контактов, и в первую очередь организация закупок вооружения и стратегических материалов.

И опять длительный путь из Москвы в Архангельск к Британии с дальнейшим перелетом (через Монреаль) в Соединенные Штаты Америки. В работе миссии также принимал участие генерал-майор инженерно-технической службы А.К. Репин. Только 26 июля миссия прибыла в Нью-Йорк, где ее встречал посол Советского Союза в США К.А. Уманский, официальные лица, а также значительное число журналистов и фотокорреспондентов.

В тот же день миссия вылетела в Вашингтон и сразу же начались первые встречи. Ф.И. Голиков в своих воспоминаниях дает достаточно подробную картину хода переговоров. За неполные полтора месяца пребывания в США советская военная миссия встречалась (порой не по одному разу) и вела переговоры практически со всеми должностными лицами, влиятельными политиками, представителями бизнес-кругов. «Тактика проволочек в действии» - так глава миссии охарактеризовал позицию должностных лиц США.

В первые дни переговоров периодические издания довольно скупо освещали 


\section{5 лет ПОБЕДЫ}

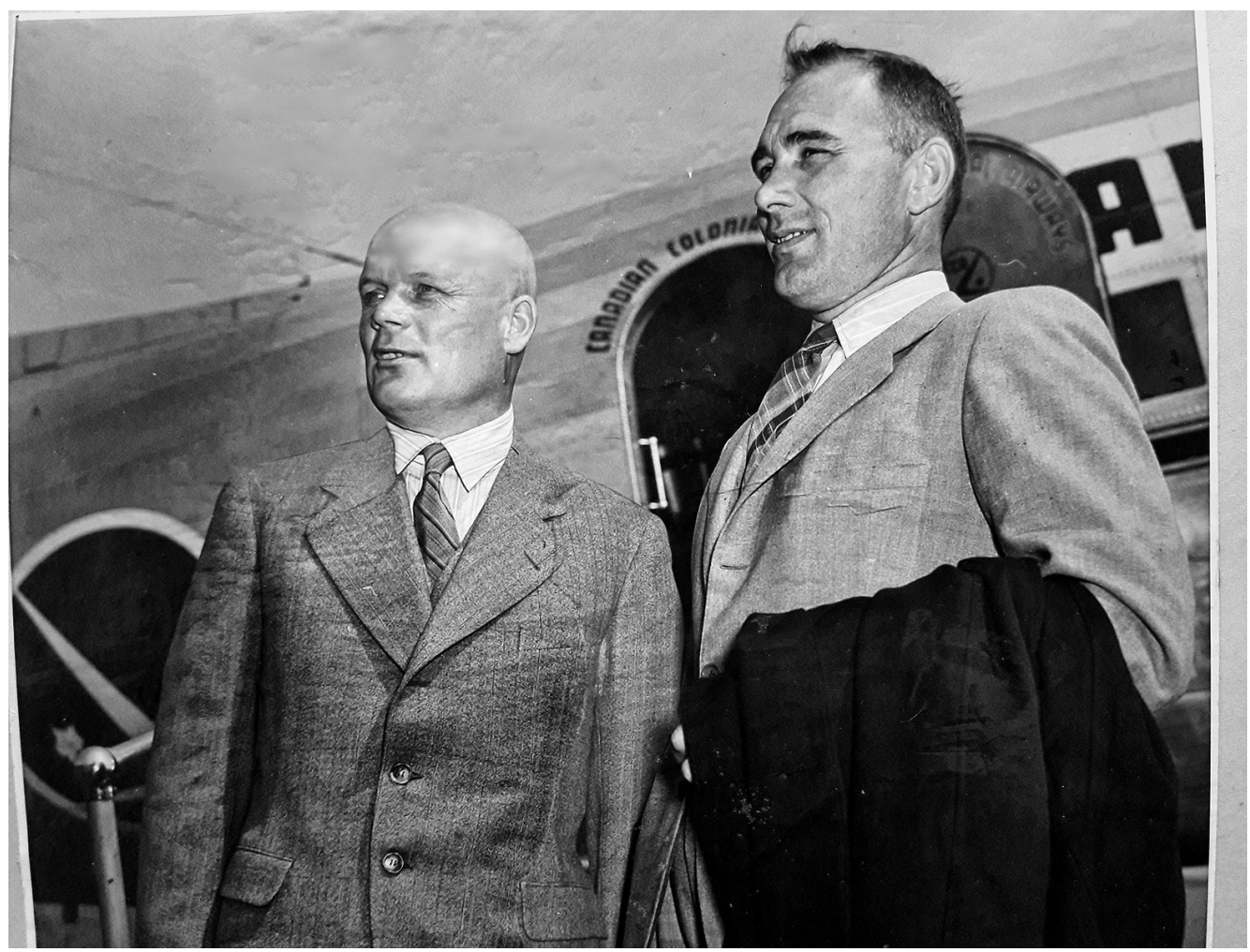

Ф.И. Голиков, А.К. Репин перед вылетом в Нью-Йорк

работу миссии, ограничиваясь лишь информационными материалами. Это отмечали и сами газеты. Tак, The Sunday News (Пенсильвания) отмечала, что нельзя перекладывать ответственность за недостаточное освещение темы переговоров на саму прессу, объясняла «сухость» материалов тем, что подробности (переговоров) изданиям не известны 20.

Члены миссии были разочарованы первой встречей с заместителем государственного секретаря США С. Уэллесом, состоявшейся сразу после прилета в Вашинпон. «С одной стороны, - пишет Голиков, - обнадеживающие заверения и тут же предупреждение о том, что реализация наших запросов произойдет не скоро и лишь частично»21. В своей записной книжке Голиков отметит, что Уэллес «Строг. Сух. Формален. Скуп. Скрытен»22. Непривычного к публичности генерала удивила просьба «пятикратного выполнения требований фотокорреспондентов поздороваться за руку»23. Эта фотография была опубликована 28 июля в газете The Daily Mail (штат Мэриленд) без комментариев ${ }^{24}$. И последующие встречи проходили в такой же тональности. Как отмечает Ю.В. Рубцов «американцы готовы были удовлетворить заявки Советского Союза лишь в незначительной степени» 25 .

Большую надежду миссия возлагала на встречу с Президентом США Ф. Рузвельтом, которая состоялась 31 июля 1941 г. Голиков писал: «Мы сразу же почувствовали благожелательное отношение Президента Соединенных Штатов Америки к представителям Советского государства. Ф. Рузвельт держался просто, непринужденно, был внимателен к каждому из 


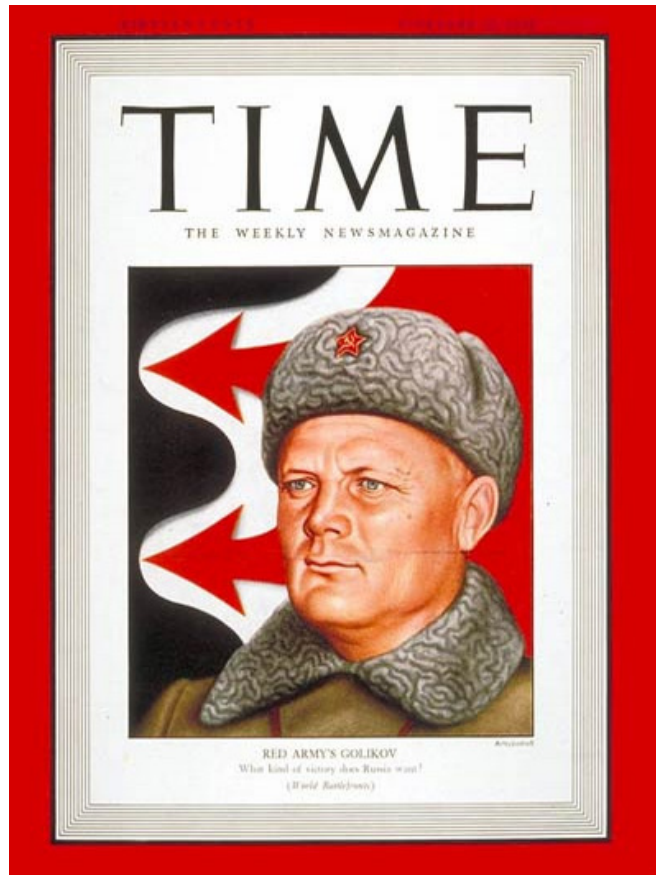

Обложка журнала Time 22 февраля 1943 г.

участников встречи»26. Это подтверждал и тот факт, что вместо отведенных на встречу 15 минут, она продолжалась 45. В ходе беседы члены советской делегации подробно охарактеризовали положение дел, связанных с пребыванием миссии в США. К.А. Уманский отметил, что Ф.И. Голиков и A.К. Репин находятся в «скверном настроении», так как вопросы решаются медленно или не решаются вообще.

Во время беседы с президентом удалось обсудить многие конкретные вопросы: содержание заявки, которую Рузвельт рассмотрел по пунктам. Президент сам составил список, в котором отметил, что могло быть предоставлено советской стороне. Также обсуждались, например, маршруты и способы транспортировки самолетов из США непосредственно в СССР, на Дальний Восток. Рузвельт согласился с необходимостью ускорения темпов помощи, подчеркнув, что необходимо отправить материалы в ближайшие два-три месяца.

Встреча с Президентом Рузвельтом более подробно освещалась в прессе, но акцент в этих публикациях делался именно на значение помощи Соединенных Штатов Советскому Союзу. Так, нью-йоркское издание The Dunkirk Evening Observer подчеркивает, что встреча президента и членов миссии прошла в теплой атмосфере. США готовы оказать помощь СССР, и Советская военная миссия впечатлена тем, насколько Президент Рузвельт хорошо ориентируется в различных военных областях ${ }^{27}$.

The New York Times также приводила слова генерала Голикова, который отметил, что «...очень легко было обсуждать военные вопросы с вами, президент»; «...чувствуется, что Президент Рузвельт очень хорошо знаком со всем комплексом проблем»28. Газета подчеркивала, что Советская военная миссия каждый день обсуждает в Государственном департаменте вопросы размещения заказов в США. В этом смысле миссия выполняет те же функции, что и миссия специального представителя президента США Г. Гопкинса, который в это время находился в Москве, где вел переговоры с И.В. Сталиным²9.

Прямо противоположное впечатление у членов миссии сложилось от встречи, которую давно ожидали, - с Г. Гопкинсом. Она состоялась 20 августа после возвращения Гопкинса из Москвы. Голиков писал в своих воспоминаниях: «Гопкинс отклонил наши усилия добиться помощи оружием в августе-октябре, сведя всё к дальнейшим планам не раньше весны»зо.

Такие «качели» в период переговоров в отношении к представителям миссии и их запросам проявлялись практически на протяжении всего пребывания Голикова в США. Например, глава миссии назвал «ругательной» встречу с генералом Бернсом. В записной книжке он даст не совсем дипломатичную характеристику своего 
ощущения после встреч текущего дня: «Настроение матерное. Злое». При этом, например, беседу с министром финансов Моргентау он назовет «чрезвычайно интересной и содержательной»31.

Как показал весь ход переговоров, очень трудно было преодолеть дистанцию между словом и делом. Ю.В. Рубцов писал: «То, что для СССР было вопросом жизни и смерти, для западных демократий представляло собой лишь новый вариант стратегической обстановки». Соединенные Штаты (и Великобритания) имели свои собственные интересы. Они в чем-то совпадали с интересами Советского Союза, а в чем-то нет 32 .

О «собственных интересах» писали американские газеты. В заметке газеты The Nassau Daily Review-Star (штат НьюЙорк) найдем только упоминание о том, что советская миссия продолжает работу. В материале особо выделяется точка зрения Г. Гопкинса, его обещание оказать «всевозможную и незамедлительную» помощь СССР. Газета приводит высказывание адмирала Уильяма Стендли, который считает необходимым поддержать союзников, в противном случае США могут оказаться в одиночестве перед угрозой возможного военного вторжения нацистов ${ }^{33}$.

Несмотря на трудности в период ведения переговоров Советской военной миссии удалось сделать немало: в первую очередь была достигнута договоренность по организации и транспортировке в СССР вооружения и военных материалов. 31 августа в Архангельск с Британских островов прибыл первый конвой, 30 августа из Нью-Йорка вышел первый транспорт с вооружением.

Большое значение для развития союзнических отношений сыграла Московская конференция трех держав, которая проходила 29 сентября - 1 октября. В работе конференции принял участие и генерал-лейтенант Ф.И. Голиков (он вер- нулся в Москву 13 сентября). Важным шагом стало подписание в начале ноября Ф. Рузвельтом указа о распространении закона о ленд-лизе на СССР. Филипп Иванович Голиков в это время уже был в действующей армии. Он находился в г. Кузнецке Пензенской области, где занимался формированием 10-й (резервной) армии, которая получит свое боевое крещение в Битве за Москву.

\section{Заключение}

На основании проведенного обзора указанных британских и американских изданий можно сделать вывод, что в первые дни проведения переговоров газеты широко освещали работу Советской военной миссии.

Британская пресса неоднократно подчеркивала, что у обеих стран есть общий интерес в борьбе против нацизма, положительно отзывалась не только о самих переговорах, но и о членах миссии, представляя их «главными военными экспертами», а также поддерживала борьбу советского народа против фашистской Германии.

В отличие от британских коллег американская пресса ограничивалась сухим изложением фактов, акцентируя внимание на готовности США помочь Советскому Союзу, на значимости этой помощи.

Примечательно, что американская пресса вернулась к теме переговоров 1941 г., но несколько в ином ракурсе: 22 февраля 1943 г. журнал Time вышел в свет с портретом Ф.И. Голикова на обложке, на тот момент генерал-полковника, командующего Воронежским фронтом. В редакционной статье, посвященной успешным операциям фронта, Time «вспомнил» работу Голикова в качестве руководителя миссии: «...он молод: 45 лет [здесь фактическая ошибка - в феврале 1943 г. Голикову было 42 года. - В.Ш.]. Он боролся в годы революции. Он выпускник Военной академии имени М. Фрунзе. Он один из немногих красных 
генералов, которые непосредственно зна- вопросам поставок. В США Голиков вел комы с союзниками России. Вскоре после переговоры и вел себя больше как таинначала войны он был отправлен в Вели- ственный человек, нежели как прибывшая кобританию и США для переговоров по знаменитость» 34 .

\section{Примечания}

${ }^{1}$ Братья и сестры. Обращение Иосифа Сталина к советскому народу 3 июля 1941 года // Военное обозрение. 2018. Июль, 3. Режим доступа: https://topwar. ru/143885-bratya-i-sestry-obraschenie-iosifa-stalina-k-sovetskomu-narodu-3iyulya-194l-goda.html

2 Лота В.И. ГРУ: испытание войной. М.: Кучково поле, 2010; Рубцов Ю.В. Генеральская правда. 1941-1945. М.: Вече, 2012.

3 Голиков Ф.И. Записки начальника Разведупра. М.: Родина, 2018. С. 89.

4 Бережков В.М. Рождение коалиции. М.: Междунар. отношения, 1975.

5 Ржешевский О.А. История второго фронта: война и дипломатия. М.: Знание, 1988.

6 Голиков Ф.И. Указ. соч. С. 92-93.

7 Рубцов Ю.В. Указ. соч. С. 36.

8 Голиков Ф.И. Указ. соч. С. 97.

9 Записная книжка маршала Ф.И. Голикова. Советская военная миссия в Англии и США в 1941 году // Новая и новейшая история. 2004. № 2. С. 92. Эта записная книжка хранится в семейном архиве Ф.И. Голикова. Филипп Иванович начал ее вести 6 июля 1941 г. в день вылета на Британские острова. В ней последовательно зафиксированы основные события - по дням - тех неполных трех месяцев, что Филипп Иванович стоял во главе миссии. Сейчас невозможно ответить на вопрос, с какой целью он начал вести этот дневник. Вряд ли летом 1941 г. думал о будущих мемуарах, вряд ли эти записи нужны были для отчетов руководству: в них очень много сугубо личных наблюдений, субъективных оценок (например, о качестве продуктов), беспокойство о семье и т.д. Тем не менее эти краткие записи очень хорошо передают атмосферу, которая складывалась на переговорах, из нее можно понять, какие трудности пришлось преодолевать членам миссии на начальном этапе формирования антигитлеровской коалиции.

10 The Guardian. 1941. July 10.

11 The Times. 1941. July 19.

12 The Times. 1941. July 10.

13 Голиков Ф.И. Указ. соч. С. 94.

14 The Guardian. 1941. July 9.

15 The Times. 1941. July 10.

16 The Times. 1941. July 9.

17 Голиков Ф.И. Указ. соч. С. 94.

18 Цит. по: Голиков Ф.И. Указ. соч. С. 105. 
19 Лота В.И. Указ. соч. С. 135.

20 The Sunday News. 1941. July 27.

${ }^{21}$ Голиков Ф.И. Указ. соч. С. 120-121.

22 Записная книжка маршала Ф.И. Голикова. С. 96.

23 Там же.

24 The Daily Mail. 1941. July 28.

25 Рубцов Ю.В. Указ. соч. С. 46.

26 Голиков Ф.И. Указ. соч. С. 146.

27 The Dunkirk Evening Observer. 1941. August 1.

28 Цит. по: Голиков Ф.И. Указ. соч. С. 155.

29 The New York Times. 1941. August 1.

30 Записная книжка маршала Ф.И. Голикова. С. 110.

31 Там же. С. 10.

32 Там же. С. 88.

33 The Nassau Daily Review-Star. 1941. July 28.

34 Time. 1943. February 22. 